\title{
Threats and conservation of cervus elaphus hanglu
}

\begin{abstract}
Hangul being the state animal of Jammu and Kashmir was once found in a contiguity through Sindh and Iran, and converging with the Central Asian red deer populations, but today these deer dwell within a single $141 \mathrm{sq}$. km protected area, the Dachigam National Park, in the state of Jammu and Kashmir. The species is at risk of extinction and also has been categorised in critically endangered ones in IUCN Redlist. Their number has declined dratically due many factors, like fuelwood and timber extraction, grass cutting, overgrazing, charcoal making, fishing and construction of cement factories and gulf course near its habitat, encroachment, poaching, population inbreeding and predation by leopard. Projects like Hangul project and Capitive greeding programme initiated by state authorties have not proven to be promising, so there is a need to develope an effective management programme and to organize awareness camps for conservation of Hangul.
\end{abstract}

Volume 3 Issue 6 - 2018

\author{
Riyaz A Bhat,' Mohd 'Yatoo,' 'Muheet,' \\ Farukh Mehraj, ${ }^{2}$ Oveas R Parray' \\ 'Department of Veterinary Medicine, Sher-e-Kashmir University \\ of Agricultural Sciences and Technology, India \\ ${ }^{2}$ Department of Animal Nutrition, Faculty of Veterinary Sciences \\ \& Animal Husbandry, Sher-e-Kashmir University of Agricultural \\ Sciences and Technology, India
}

\begin{abstract}
Correspondence: Riyaz A Bhat, Department of Veterinary Medicine, Sher-e-Kashmir University of Agricultural Sciences and Technology, India, Email koolreya22@gmail.com
\end{abstract}

Received: October 02, 2018 | Published: November 02, 2018

\section{Introduction}

Red deer is one of the most widespread deer species in the world. ${ }^{1}$ Many of the them have gone locally extinct and some are at threatened stage, inwhich the Cervus hanglu hanglu is the only surviving subspecies of red deer in the Indian sub-continent, and also has been categorised in critically endangered ones (IUCN Redlist, 2017). Cervus elaphus hanglu also known as Hangul or Kashmir red deer, has a light rump patch without including the tail and has a brown coat color with a speckling to the hairs. Buttocks are greyish white on the inner side, followed by a line on the inner sides of the thighs and black on the upper side of the tail. The hangul has antler consists of 5 tines with strongly inward curved beam, while the brow and bez tines are usually close together and above the burr.As per the leading news paper from Kashmir Valley which documented that in the beginning of 20th century Hangul population in Kashmir was recorded as 5000 but it has now declined to 182 as per the census report 2017 of J \& K government. $^{2}$

Historically, the hangul was commonly found in the mountains of Kashmir Himalayas, Chenab valley and some parts of Chamba district in Himachal Pradesh. ${ }^{3,4}$ Over time, the hangul deer lost its habitat due to environmental and anthropogenic pressures particularly because of deforestation, degradation and encroachment., ${ }^{3,5}$ Maharaja Hari sing prepared a Kashmir's shikar map which depicts that Hangul was distributed in a radius of 40km spreading from Karen in Kishenganga catchmentsover to Dorus in Lolab valley, Erin catchments in Bandipora to Chamba district of Himachal Pradesh through Baltal to Aru, Tral, and Kashtwar. ${ }^{6}$ However, the only expendient population is centred in Dachigam National Park and adjoining protected areas in the Greater Dachigam landscape north-east of Srinagar. ${ }^{4}$ The catchment area of Dachigam National Park is folded in between the opposing faces of high mountainous ridges, on the right of Lidder and along the left of the Sindh on its eastern and western boundaries respectively. A wide range of surveys from 2000 to 2009 suggest that the distribution of Hangul is restricted to $351 \mathrm{~km}^{2}$ of approximately $885 \mathrm{~km}^{2}$ of its possible range. ${ }^{7}$ The Hangul was also found in conservation reserves of Bren-Nishat, including Cheshmashahi Forest Reserve, Khrew, Khanagund, Shikargh and Overa Wildlife Sanctuary. Individuals were also sighted between Surfrao and Akhal Blocks of the Sindh Forest Division and north of the Holy Amarnath Cave. However, they have not been observed outside Dachigam. The aim of this paper is to examine the threats and conservation of cervus elaphus hanglu using documented evidences.

\section{Threats and conservation}

National Park is believed to be viable and all predominantly comprise scattered isolated. ${ }^{7,8}$ Yet several red deer species have become locally extinct from Albania, Mexico and Nepal, ${ }^{9}$ and several others are severely threatened. ${ }^{10,11}$ Among the latter, the hangul or the Kashmir red deer (Cervus hanglu hanglu) Lorenzini \& Garofalo $^{12}$ is the only surviving sub-species of red deer in the Indian sub-continent, and also classified as critically endangered (IUCN Redlist, 2017). Once thought to be a single population cline, was found in a contiguity through Sindh and Iran, and converging with the Central Asian red deer populations, today these deer dwell within a single $141 \mathrm{~km}^{2}$ protected area, the Dachigam National Park, in the

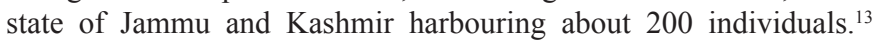
Unfortunately, their number declined from about 5,000 animals in the beginning of the 20th century to as low as 150 animals by 1970 due to the threat posed by habitat destruction, over-grazing by domestic livestock, and poaching. Much of the earlier published material was by the distinguished E. P. Gee, a member of the Bombay Natural History Society. Fiona Guinness and Tim Clutton-Brock, both noted deer experts, had visited Kashmir and had gathered some useful field data, which confirmed that Hangul numbers were at a dangerously low level and were at a risk of extinction. Upper danchigam, used to be the traditional breeding grounds of the hangul deer which is now occupied by Gujar shepherds and their dogs in summer (refer the book a life with wildlife by M.K.Ranjitsinh).

Hangul which is known for its magnificent antlers with 11 to 16 points, was once distributed widely in the mountains of Kashmir. During the 1940s, their number was believed to be about 3,000-5,000. As per the census in 2008 , only around 160 exist.The hangul sex ratio was 21 males per 100 females and the fawn female ratio showed a significant decline from 23 to 9 fawns as per census 2004/2006 carried out by Department of Wildlife Protection and subsequent analysis by Widlife institute of india (WII). Hangul an endangered species is near to its extinction due to many factors including physical, biological and other anthropogenic disturbances. Physical factors include fuelwood and timber extraction, grass cutting, overgrazing, charcoal making, fishing andconstruction of cement factories and gulf course near its habitat. ${ }^{14}$ Poaching, population inbreeding and predation by leopard 
are the main biological factors responsible for decline of Hangul population. Several govt departments like sheep breeding farm ,fisheries department, water works and irrigation are also thought to pose threat to Hangul. ${ }^{8}$ A number of studies on Hangul suggest that disease transmission from the sheep and goats also make the species vulnerable. ${ }^{6}$ In 2015,the Hangul population estimation survey was conducted in which the count of Hanguls in and around their habitats in Kashmir valley is just 186 (India Today 2017, January). The animal is now at a high risk of extinction, they are now scattered within $141 \mathrm{~km}^{2}$ of the Dachigam National Park located on foothills of Zabarwan range on the outskirts of Srinagar. However, the state of Jammu and Kashmir, along with the IUCN (International union for conservation of Nature and Natural resources) and the WWF (WorldWide Fund) prepared a project for the protection of these animals known as Project Hangul. This has achieved great results and the population increased to over 340 by 1980 . Also many steps have been initiated by government like Enforcement of J and K Wildlife Protection Act 1978, deployment of antipoaching squads at strategic points,strict regulation of grazing and improvement of habitat conditions. ${ }^{15}$ In 2008 a captive breeding programme was announced by the state government, which was given financial asistance of Rs 22 crore from National Zoo Authority of India to build breeding centre for Hangul but the department faced difficulty in catching Hangul and the project did not take off for five years. ${ }^{16-19}$

\section{Conclusion}

Hangul which is the state animal of $\mathrm{J}$ and $\mathrm{K}$ is at a threat to get extinct due to risk posed by the activities like Poaching, overgrazing, predation and other antropogenic disturbances. A number of programmes initiated by the state authorties in order to conserve the Hangul have not proved much effective. There is a need to conduct research on management aspects and to develope an effective management programme for Dachigam National Park inorder to decrease the risk factors and also to organize awareness camps for people on conservation of Hangul.

\section{Acknowledgements}

None.

\section{Conflict of interest}

Author declares that there is no conflict of interest.

\section{References}

1. Dolan JM. A deer of many lands-a guide to the subspecies of the red deer Cervuselaphus. Zoonooz. 1988;62:20.

2. Akmali M. Hangul population declines to 182. India: Greater Kashmir news paper; 2018.
3. Schaller GB. Observation on Hangul or Kashmir stag (Cervuselaphus hanglu). J Bombay Nat HistSoc. 1969;66(1):1-7.

4. Mukesh, Kumar VP, Sharma LK, et al. Pragmatic perspective on conservation genetics and demographic history of the last surviving population of Kashmir red deer (Cervuselaphus hanglu) in India. PLoS One. 2015;11:10(2).

5. Charoo SA, Sharma LK, Sathyakumar S. Distribution and relative abundance of Hangul (Cervuselaphus hanglu) in Dachigam national park. Spanish Journal of Wildlife. 2010;71-184.

6. Wani AS. Hangul faces extinction threat. India: Greater Kashmir News Paper; 2007.

7. Ahmad K, Qureshi Q, Nigam P et al. Status and conservation of Hangul (Cervuselaphus hanglu) in its relic range areas outside Dachigam National Park. Indian Forester. 2013;139:883-887.

8. Qureshi Q, Shah N, Wadoo AR, et al. Status and distribution of hangul Cervuselaphus hanglu Wagner in Kashmir, India. Journal of the Bombay Natural History Society. 2009;106:63-71.

9. Lovari S. Cervuselaphus, In: IUCN 2013, IUCN Red List of Threatened Species. 2008.

10. Flint V, Pereladova OB, Mirutenko MV. Program for Bukara deer restoration in the USSR. All Union Research Institute for Nature Protection and Reserve Services, State Committee on Nature, USSR, 1989.

11. Hmwe SS, Zachos FE, Eckert I, et al. Conservation genetics of the endangered red deer from Sardinia and Mesola with further remarks on the phylogeography of Cervuselaphuscorsicanus. Biol J Linn Soc Lond. 2006;88:691-701

12. Lorenzini R, Garofalo L. Insights into the evolutionary history of Cervus (Cervidae, tribe cervinae) based on Bayesian analysis of mitochondrial marker sequences, first indication of a new species. J Zoolog Syst Evol Res. 2015;53(4):340-349.

13. Kurt F. Kashmir deer (Cervuselaphus hanglu) in Dachigam, Working meeting of the IUCN Deer Specialist Group, Longview. 1977.

14. Naqash R. Wildlife Conservation, Kashmir has taken a step to conserve its prized Hangul deer, Is it too little, too late. 2017.

15. Aziz MA, Shazia L, Fayaz AL. An Overview of Hangul (cervus elaphus hanglu,Wagner) in Dachigam National Park, Kashmir (India).

16. Zehra M. Hangul conservation takes back seat in Kashmir. Down to Earth. 2017.

17. India Today. Hangul population in Kashmir has declined: JK govt, India, 2017

18. Mustafa GS, Ulfat J, Bilal AB, et al. Cause of decline of critically endangered Hangul deer in Dachigam National Park (India): A review. International Journal of Biodiversity and Conservation. 2011;3(14):735738. 